\title{
Innovation of University Course Teaching Mode Based on Node Method Project Management
}

\author{
Jiade Wang ${ }^{1, a}$ \\ ${ }^{1}$ Kunming University of Science and Technology Oxbridge College \\ ${ }^{a}$ Email:46976117@qq.com
}

\begin{abstract}
Under the background of informatization, digitization, networking and intellectualization, the traditional teaching mode of colleges and universities cannot meet the needs of the development of modern society. In order to cultivate modern and high-quality talents, colleges and universities need to build more first-class courses with advanced, innovative and challenging degrees, which is bound to carry out a series of teaching reforms, and the fundamental of which lies in the innovation of teaching mode. Based on the teaching practice and innovation results, this paper puts forward the ideas and methods of teaching mode innovation in colleges and universities under the guidance of node method project management, which lays a foundation for the model, standardization and information teaching.
\end{abstract}

Keywords : node method, teaching reform, teaching mode, innovation.

\section{INTRODUCTION}

In the course teaching of colleges and universities in Our country, the low efficiency and boring teaching mode which mainly focuses on classroom teaching and supplemented by homework is generally continued, which cannot meet the requirements of cultivating modern high-quality talents and does not accord with the direction of teaching reform of education authorities. In recent years, the wide application of various Internet teaching platforms as teaching AIDS has greatly promoted teaching reform and innovation, and both teaching efficiency and teaching effect have been significantly improved.

How to play a maximum value of Internet teaching platform, give full play to the initiative and enthusiasm of teachers and students, make the teaching always under control, not by teachers' and students' subjective mood changes affect the teaching effect, to establish a teaching model of estimation, standardization, informationization is a worthy subject for education practitioners $^{[1]}$.

Node method project management is a new method and tool of modern project management ${ }^{[2]}$. It has the characteristics of simplicity, practicality and efficiency. It can construct a model, standardization and information management mode from the perspective of system, whole and organization, and can be used as the guiding ideology of teaching mode innovation in colleges and universities. The popularization and deepening of the Internet teaching platform can be used as a technical tool for the innovation of undergraduate teaching mode. Taking the node method project management as the guiding ideology and the Internet teaching platform as the tool, we can realize the innovation of the teaching mode of college courses and establish a model, standardization and information efficient teaching mode.

\section{THE THEORETICAL BASIS AND MANAGEMENT MODE OF NODE METHOD PROJECT MANAGEMENT}

\subsection{Theoretical basis of node method project management}

Node method project management is based on modern project management knowledge system, management practice, innovation results, concise, practical, effective as the goal, from the perspective of the whole to the part to build a new project management method and new tools. By carrying out project management from the perspective of system, whole and organization, managers can know their position and responsibilities in the whole project. Through the drip accumulation of control results at each node and stage, the success of local management can achieve the 
success of overall management ${ }^{[3]}$.

Node method project management from the practical and effective, gradually improve, sustainable management Angle to establish a quantitative, continuous, sustainable project management organization concept and knowledge system, provides a system, standard, can improve the project management of new methods and new tools ${ }^{[3]}$.

\subsection{Node method project management mode}

Node method project management is guided by organizational management, based on objective management, process management and results management, focusing on the control of key nodes in each stage of the project, and carrying out targeted organizational control such as rule organization, process organization, target organization, responsibility organization and coordination organization of the whole, stage and node. The closed-loop management of project establishment $\rightarrow$ decision-making organization $\rightarrow$ goal formation $\rightarrow$ implementation organization $\rightarrow$ achievement formation $\rightarrow$ evaluation organization $\rightarrow$ project replication is realized, and a management system of "book with text" model organization, "train with track" standardized management and control, and "weights and measures" information measurement is formed ${ }^{[3]}$.

Node method project management divides the project into three stages: decision-making, implementation and evaluation. According to different projects or managers, each stage can be subdivided into different interrelated nodes. The success of node control ensures the success of stage management, and the success of stage control ensures the success of overall project management ${ }^{[3]}$. Node method project management model is shown in Figure 1.

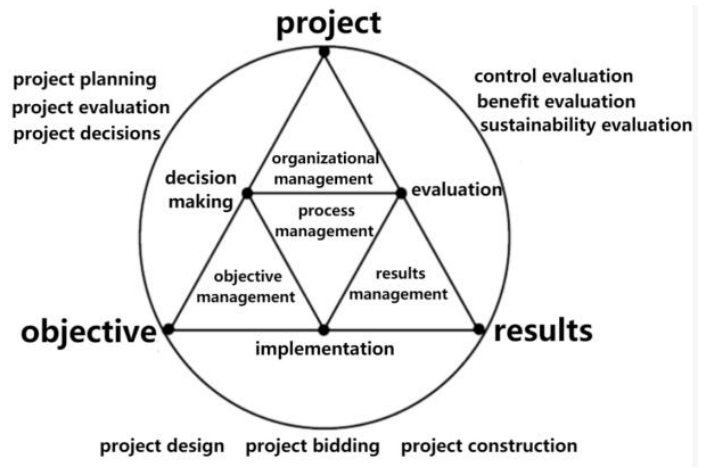

Figure 1 Node method project management model

\section{THE NECESSITY OF INNOVATING THE TEACHING MODE OF COLLEGE COURSE}

\subsection{The main problems of current course teaching mode}

For a long time, the course teaching in colleges and universities is mainly based on traditional multimedia classroom teaching, aiming at the completion of teaching tasks. There are problems such as insufficient teaching hours, monotonous and boring forms, which cannot fully and effectively strengthen the training of important knowledge points, and lack of interactive, active and harmonious teaching atmosphere. These problems lead to low teaching efficacy of teachers, poor learning effect of students, the formation of teachers passive teaching, poor teaching, casual teaching, students passive learning, do not want to learn, casual learning of the bad cycle, teachers and students will have a lot of unreasonable and helpless reasons for not teaching well and learning well.

\subsection{Innovative thinking of course teaching mode}

In view of the problems of course content increasing but not decreasing, class hours decreasing but not increasing, teachers being difficult to teach, poor teaching results, students being tired of learning and poor academic performance, its fundamental reason is the traditional exam-oriented education problem, resulting in students' efforts and final results are not proportional, so most of the students pay more attention to the results than the process, resulting in students difficult to manage, teachers difficult to teach.

To solve these problems, we must take the student as the center and teaching process management as the guidance, application of efficient, practical and innovative systems theory, using the Internet teaching platform as a tool to innovate the course teaching mode, formulate more reasonable evaluation methods and teaching methods in teaching design, pay more attention to the evaluation of teaching process and the improvement of students' learning ability, make course more attractive, let students have pressure, have goals, have motivation.

\subsection{Innovation goal of course teaching mode}

Based on the problems existing in current teaching and the urgent needs of teaching reform, course teaching mode innovation centering on the following objectives:

(1) Promote the combination of online and offline teaching mode, enrich the content and resources of online courses, effectively utilize the fragmented time of students, increase the freedom of learning, and ensure 
students are able to learn or repeat learning at any time and anywhere.

(2) Attach importance to the preview effect, arrange preview tasks reasonably and have control means in the preparation before class, so that students have a macro concept of the current course content, can "go to class with questions", and promote students to listen actively and carefully in class.

(3) Enrich classroom teaching activities, formulate detailed quantifiable evaluation indicators, so that the final results of students more real, more fair and reasonable.

(4)Properly improve the difficulty of homework, enhance knowledge application ability, and gradually realize intelligent marking.

(5)Increase the burden scientifically, enabling students to experience the pressure of "it takes a jump to get" and the power of "you can reach it with a hop".

(6)Establish a perfect testing and evaluation system, integrate the teaching platform with the educational administration system, and gradually form a modeling, standardized and informationized teaching management system.

(7)Properly strengthen the teaching work before and after class, to create conditions for the integration of ideological politics and course teaching.

\section{INNOVATION PATH OF COURSE TEACHING MODE BASED ON NODE METHOD PROJECT MANAGEMENT}

Based on the nodal method project management theory, combined with the teaching practice and teaching reform results, with the goal of simplicity, practicality and efficiency, from the perspective of the whole to the part, the teaching process and the teaching system are reconstructed, and a new course teaching mode is created through the following steps ${ }^{[4]}$.

\subsection{Establish the course teaching thought}

The node method project management guides the innovation of teaching mode ${ }^{[4]}$, and its management theory is the theory of teaching mode innovation.

(1)Teaching philosophy:organizations determine rules, goals guide actions, processes control results, and results enhance management.

(2)Teaching goal:overall teaching control is the best.

(3)Teaching material:realize "book with text" in teaching mode, idea, exchange and communication;realize "train on track" in teaching methods, techniques, tools and achievements;realize"weights and measures" in teaching assessment, evaluation, summary and accumulation.

(4)Teaching mode:model organization, standardized control, information measurement.

\subsection{Design course teaching model}

The teaching model of node method is designed according to the whole process project management model of node method. The process is as follows:

(1)Teaching system:course teaching must have a complete teaching process, that is, course $\rightarrow$ teaching design $\rightarrow$ goal formation $\rightarrow$ teaching implementation $\rightarrow$ achievement formation $\rightarrow$ teaching evaluation $\rightarrow$ model duplication, this is a complete, closed loop, circular course teaching system, should have the pattern, sustainability and universality.

(2)The main stage: course teaching can be divided into teaching design, teaching implementation and teaching evaluation stages.

(3)The key link:course teaching can be divided into courses, objectives and results.

(4)Teaching elements : according to the course teaching process, teaching elements are divided into organizational management, objective management, process management and results management.

(5)The key nodes: the stage of teaching design can be divided into nodes of syllabus, teaching process and teaching plan; the stage of teaching implementation can be divided into nodes of preview, lecture and homework; and the stage of evaluation can be divided into nodes of process evaluation, skill test and final assessment. The course teaching model of node method is shown in Figure 2.

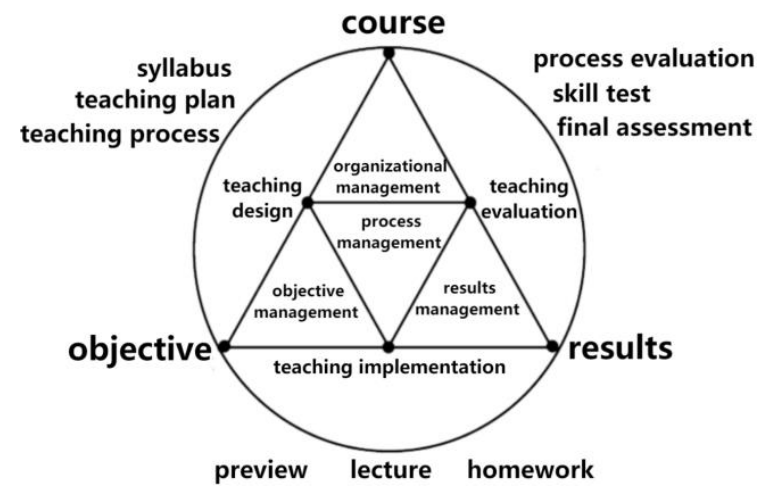

Figure 2 The course teaching model of node method

\subsection{Design course teaching organization process}

Course teaching organization process of node method is the expansion and extension of the course teaching model of node method, so as to establish the working mode of delivering and receiving nodal results 
and ensure that the teaching process is organized and implemented in accordance with the same method, and make the teaching results of each stage and node can be communicated in a system of "book with text", quantified correction of "train with track" and assessment of "weights and measures" ${ }^{[4]}$. The course teaching organization process of node method is shown in Table 1.

Table 1.The course teaching organization process of node method

\begin{tabular}{|c|c|c|c|c|c|}
\hline The main stage & The key nodes & $\begin{array}{c}\text { organizational } \\
\text { management }\end{array}$ & $\begin{array}{c}\text { objective } \\
\text { management }\end{array}$ & $\begin{array}{c}\text { process } \\
\text { management }\end{array}$ & $\begin{array}{c}\text { results } \\
\text { management }\end{array}$ \\
\hline \multirow{3}{*}{ teaching design } & syllabus & \multirow{4}{*}{$\begin{array}{c}\text { The teaching } \\
\text { system }\end{array}$} & \multirow{4}{*}{$\begin{array}{l}\text { The quality of } \\
\text { teaching }\end{array}$} & \multirow{4}{*}{ preview } & \multirow{5}{*}{$\begin{array}{c}\text { Daily } \\
\text { performance }\end{array}$} \\
\hline & teaching process & & & & \\
\hline & teaching plan & & & & \\
\hline \multirow{3}{*}{$\begin{array}{c}\text { teaching } \\
\text { implementation }\end{array}$} & preview & & & & \\
\hline & lectures & \multirow{2}{*}{$\begin{array}{c}\text { Teachers } \\
\text { management }\end{array}$} & \multirow{2}{*}{$\begin{array}{c}\text { The teaching } \\
\text { process }\end{array}$} & \multirow{2}{*}{ lectures } & \\
\hline & homework & & & & Skill scores \\
\hline \multirow{3}{*}{$\begin{array}{l}\text { teaching } \\
\text { evaluation }\end{array}$} & $\begin{array}{c}\text { process } \\
\text { evaluation }\end{array}$ & \multirow{3}{*}{$\begin{array}{c}\text { Student } \\
\text { management }\end{array}$} & \multirow{3}{*}{$\begin{array}{l}\text { Teaching } \\
\text { resources }\end{array}$} & \multirow[t]{3}{*}{ homework } & \multirow[t]{3}{*}{ The final result } \\
\hline & skill test & & & & \\
\hline & final assessment & & & & \\
\hline
\end{tabular}

\subsection{Subdivide teaching nodes and management elements}

On the basis of the teaching model and organizational process of node method, the teaching nodes and management elements are subdivided according to different courses or teachers.Node subdivision is based on each stage of teaching to ensure that the objectives are clear, the control is in place, the results are quantified and deliverable, and the results of the previous node serve as the foundation of the next node.Node subdivision should have clear and scientific teaching objectives, such as planning "how much we want to manage" from the perspective of sensibility, evaluating "how much we can manage" from the perspective of resources, and determining "how much we should manage" from the perspective of science ${ }^{[3]}$. The subdivided teaching nodes and management elements are shown in Table 2.

Table 2.The subdivided teaching nodes and management elements

\begin{tabular}{c|c|c|c}
\hline \multirow{2}{*}{ The main stage } & $\begin{array}{c}\text { objective } \\
\text { management }\end{array}$ & $\begin{array}{c}\text { process } \\
\text { management }\end{array}$ & $\begin{array}{c}\text { results } \\
\text { management }\end{array}$ \\
\hline \multirow{4}{*}{ teaching design } & syllabus & Knowledge combing & Key points and Difficulties \\
\cline { 2 - 4 } & Key points and Difficulties & Knowledge structure & teaching process \\
\cline { 2 - 4 } teaching & teaching process & teaching method & teaching plan \\
\cline { 2 - 4 } implementation & teaching plan & Preparation before class & Be familiar with the knowledge \\
\cline { 2 - 4 } & Understand the knowledge & Classroom practice & Understand the knowledge \\
\cline { 2 - 4 } & Knowledge application & Key and Difficult points & Master the knowledge \\
\cline { 2 - 4 } & Master the knowledge & homework & Strengthen knowledge \\
\hline \multirow{2}{*}{ teaching } & Ordinary performance & Process evaluation & Daily performance \\
\cline { 2 - 4 } & Ability to apply & Homework evaluation & Skill scores \\
\cline { 2 - 4 } & Comprehensive knowledge & The final assessment & The final result \\
\hline
\end{tabular}

\subsection{Design course teaching control form}

Node method teaching control form is not only a technical tool of node method course teaching, but also the basis of course teaching informationization. Teaching control forms are used to implement systematic and overall course construction and teaching organization from top to bottom. Meanwhile, forms are used to 
record the whole process of teaching and teaching results, and quantitative and continuous teaching feedback is carried out from bottom to top.The management flow from top to bottom and the information flow from bottom to top are organically organized in the form of forms, which show the teaching process and express the standardized and informationized teaching results.

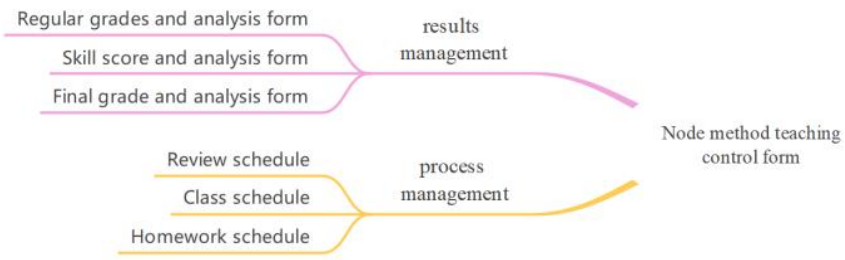

The design of the node method course teaching control form focuses on improving teaching quality and teaching efficiency. The specific content and form of the forms can be different according to different teachers and courses. Sub-forms can also be designed under the form ${ }^{[4]}$. The classification of teaching control form of node method is shown in Figure 3.

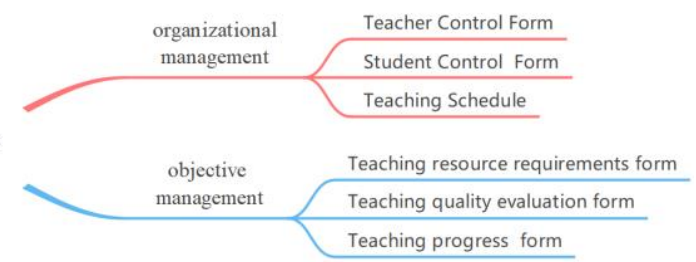

Figure 3 The classification of teaching control form of node method

\subsection{Course teaching information construction}

Based on the information of the course teaching control form, a digital and informationized teaching platform is created, and a modular, standardized and informationized course teaching management system is constructed to lay a foundation for the realization of intelligent teaching ${ }^{[5]}$. The functional framework of the node method teaching platform is shown in Table 3.

Table 3.The functional framework of the node method teaching platform

\begin{tabular}{|c|c|}
\hline Organizational structure & System function \\
\hline Course Related Documents & Training scheme,syllabus, Teaching plan,Teaching material,Teaching process \\
\hline Course resources & PPT courseware,Video courseware,MOOC, Virtual simulation courseware \\
\hline Management tools & $\begin{array}{l}\text { members,team, attendance, raise, Vies to answer first, Random candidate, Manual } \\
\text { candidate,discuss }\end{array}$ \\
\hline Preview management & Preview task,interactive,Preview results, Prepare evaluation \\
\hline Classroom management & $\begin{array}{c}\text { The teaching schedule,Knowledge architecture,Interaction between teachers and } \\
\text { students, Students interact ,Classroom practice,Classroom assessment }\end{array}$ \\
\hline Homework management & Homework tasks, interactive,Homework submission,Homework evaluation \\
\hline The exam management & $\begin{array}{l}\text { Exam arrangement, Review material,interactive, Filing papers, Evaluation of } \\
\text { examinations }\end{array}$ \\
\hline System management & $\begin{array}{l}\text { Rights management, Teaching mode,warning ,Educational administration } \\
\text { system,Comprehensive evaluation }\end{array}$ \\
\hline
\end{tabular}

\section{CONCLUSION}

Based on the above application research of node method project management in the innovation of college course teaching mode, the following conclusions are drawn:

(1)The deep integration of project management theory and teaching mode innovation is a new idea and method in teaching reform.

(2)It is necessary and feasible to use node method project management theory to guide the innovation of course teaching mode, and the implementation path is scientific and clear.

(3)The model, standardization and information node method course teaching mode is the fundamental guarantee to improve the teaching quality.
(4)With the teaching mode of node method, course teaching can be more detailed and quantified, which is the basis of information and intelligent teaching.

\section{ACKNOWLEDGMENTS}

This work was financially supported by scientific Research Fund of Yunnan Education Department (2021J0820).

\section{REFERENCES}

[1] Zhu Chuanwei, SHI Wenhui, Huang Min,Theoretical Analysis of innovative teaching model,in: Education Industry(12),2020,pp. 95-96.

[2] CAI Jiaming,Node Method project Management,in:Yunnan People's Publishing 
House, Yunnan,2012, pp.1-29.

[3] CAI Jiaming, Zhong Wenwu, Zhang Jianping,Node Method project Management and BIM application,in:Science

Press ,Beijing,2018,pp.43-155.

[4] Wang Jiade, Liu Peng,Research on project Management Path Based on Node Method and BIM Application,in:Project management technology19(2),2021,pp.78-82.

[5] Wang Jiade, Planning and Research of Virtual Simulation Teaching Platform for whole Process Project Management in Node Method,in:Project management technology18(2),2020,pp.47-51. 